OPEN ACCESS

Edited by:

Xinhua Yu,

Research Center Borste

(LG), Germany

Reviewed by:

Jing Yuan,

Children's Hospital of Capital Institute

of Pediatrics, China

Su-Boon Yong,

Show Chwan Memorial

Hospital, Taiwan

*Correspondence: Michael Manansala mmanan3@uic.edu

Specialty section:

This article was submitted to

Rheumatology,

a section of the journal

Frontiers in Medicine

Received: 29 July 2020 Accepted: 05 October 2020 Published: 04 November 2020

Citation:

Manansala M, Ascoli C, Alburquerque AG, Perkins $D$, Mirsaedi M, Finn P and Sweiss NJ (2020) Case Series: COVID-19 in

African American Patients With Sarcoidosis. Front. Med. 7:588527. doi: 10.3389/fmed.2020.588527

\section{Case Series: COVID-19 in African American Patients With Sarcoidosis}

\author{
Michael Manansala ${ }^{1 *}$, Christian Ascoli ${ }^{1}$, Ana Goico Alburquerque ${ }^{1}$, David Perkins ${ }^{1}$, \\ Mehdi Mirsaedi ${ }^{2}$, Patricia Finn ${ }^{1}$ and Nadera J. Sweiss ${ }^{1}$ \\ ${ }^{1}$ Department of Internal Medicine, University of Illinois at Chicago, Chicago, IL, United States, ${ }^{2}$ Miller School of Medicine, \\ University of Miami, Miami, FL, United States
}

Data on the clinical presentation and outcomes of sarcoidosis patients with coronavirus disease 19 (COVID-19) are scarce. In this case series, we identified 5 out of 238 sarcoidosis patients who are enrolled in an ongoing longitudinal observational study who developed COVID-19 during the study period and follow their clinical course. Four patients recovered completely, whereas one patient expired during hospital admission. Our preliminary experience suggests that African American patients with chronic sarcoidosis treated with disease-modifying anti-rheumatic drugs (DMARDs) or anti-tumor necrosis factor (TNF) therapy do not seem to be at increased risk of respiratory or life-threatening complications from severe acute respiratory syndrome coronavirus 2 (SARS-CoV-2) compared with the general population, although at the present time, we advocate for maintaining a high level of vigilance and strict follow-up in this patient population.

Keywords: sarcoidosis, COVID- 19, immunosuppression, DMARDs, African American (AA), SAR-CoV-2

\section{INTRODUCTION}

The recent outbreak of severe acute respiratory syndrome coronavirus 2 (SARS-CoV-2) responsible for severe acute respiratory syndrome (SARS) represents a source of concern for the management of patients with sarcoidosis (1). Within the realm of sarcoidosis, it has been shown that African Americans have 12 times the rate of age-adjusted mortality compared with similar Caucasian patients (2). This is compounded by the observation that African American patients are at disproportionately increased risk of mortality and morbidity from coronavirus disease 19 (COVID-19) (3). Data on COVID-19 in patients with sarcoidosis are scarce. Additionally, there is a concern that immunocompromised patients are at increased risk of mortality from COVID-19. Here, we report a case series describing the clinical course of five African American patients with sarcoidosis after infection with SARS-CoV-2.

\section{METHODS}

We assessed patients with sarcoidosis care established at the University of Illinois of Chicago Bernie Mac STAR Clinic who are enrolled in an ongoing longitudinal observational study for SARSCoV-2 infection during the period of March 12 to April 30, 2020. We identified five out of 238 patients (2.1\%) with confirmed SARS-CoV-2 infection by PCR and clinical symptoms consistent with COVID-19 disease. Demographic and clinical data were collected. 
TABLE 1 | Clinical characteristics of five African American sarcoidosis patients with confirmed COVID-19.

\begin{tabular}{|c|c|c|c|c|c|}
\hline & Patient 1 & Patient 2 & Patient 3 & Patient 4 & Patient 5 \\
\hline Age & 45 & 62 & 50 & 48 & 46 \\
\hline Gender & M & $\mathrm{F}$ & $\mathrm{M}$ & $\mathrm{F}$ & M \\
\hline $\begin{array}{l}\text { Sarcoidosis clinical phenotype requiring } \\
\text { treatment }\end{array}$ & Pulmonary & $\begin{array}{l}\text { Advanced } \\
\text { pulmonary }\end{array}$ & Ocular cardiac & Neurologic & Testicular \\
\hline $\mathrm{BMl}$ & 28 & 28 & 31 & 46 & 43 \\
\hline Comorbidities & Asthma & $\begin{array}{l}\text { Pulmonary } \\
\text { hypertension }\end{array}$ & $\begin{array}{l}\text { Uncontrolled } \\
\text { hypertension, } \\
\text { uncontrolled } \\
\text { diabetes }\end{array}$ & $\begin{array}{l}\text { Uncontrolled } \\
\text { hypertension }\end{array}$ & $\begin{array}{l}\text { Uncontrolled } \\
\text { hypertension }\end{array}$ \\
\hline Smoking history & None & None & Active smoker & None & Active smoker \\
\hline Sarcoid medications at the time of presentation & $\begin{array}{l}\text { Methylprednisolone } \\
8 \mathrm{mg} \text { daily }\end{array}$ & $\begin{array}{l}\text { MTX } 10 \text { mg weekly, } \\
\text { HCQ } 200 \text { mg daily, } \\
\text { methylprednisolone } \\
4 \text { mg daily }\end{array}$ & None & None & $\begin{array}{l}\text { Infliximab every } 8 \\
\text { weeks, MTX } 7.5 \mathrm{mg} \\
\text { weekly }\end{array}$ \\
\hline
\end{tabular}

BMI, body mass index; MTX, methotrexate; $H C Q$, hydroxychloroquine.

TABLE 2 | Clinical data for five African American sarcoidosis patients with confirmed COVID-19.

\begin{tabular}{|c|c|c|c|c|c|}
\hline & Patient 1 & Patient 2 & Patient 3 & Patient 4 & Patient 5 \\
\hline COVID-19 symptoms & $\begin{array}{l}\text { Dyspnea on } \\
\text { exertion, cough }\end{array}$ & $\begin{array}{l}\text { Cough, anosmia, } \\
\text { dysgeusia, myalgia }\end{array}$ & $\begin{array}{l}\text { Cough, shortness of } \\
\text { breath, fever, } \\
\text { myalgias, diarrhea }\end{array}$ & Cough, fever & Diarrhea \\
\hline Symptom duration prior to presentation (days) & 2 & 7 & 4 & 7 & 10 \\
\hline \multicolumn{6}{|l|}{ Relevant laboratories prior to presentation } \\
\hline WBC (3.9-12 thou/ $\mu$ l) & 3.8 & 7.2 & 3.9 & 6.7 & 3.9 \\
\hline Abs lymphocytes (1.3-4.2 thou/ $\mu$ l) & 1.7 & 1.7 & 1.3 & 1.9 & 1.8 \\
\hline Abs CD4 (438-1,501 cells $\left./ \mathrm{mm}^{3}\right)$ & 696 & 1,107 & - & 1,501 & 833 \\
\hline CRP (0-18 mg/L) & $<1.0$ & 6.9 & 6.8 & 4.3 & 4.9 \\
\hline ESR $(0-10 \mathrm{~mm} / \mathrm{h})$ & 8 & 19 & 16 & 64 & 21 \\
\hline \multicolumn{6}{|l|}{$\begin{array}{l}\text { Relevant laboratories at the time of } \\
\text { presentation }\end{array}$} \\
\hline WBC (3.9-12 thou/ $\mu$ I) & 4.5 & - & 3.1 & - & 2.8 \\
\hline Abs lymphocytes (1.3-4.2 thou/ $\mu$ l) & 1.4 & - & 0.9 & - & 1.2 \\
\hline Abs CD4 (438-1,501 cells/mm³) & - & - & 152 & - & 420 \\
\hline LDH (90-180 U/L) & 273 & - & 270 & - & - \\
\hline Ferritin (10-259 ng/ml) & 152 & - & 730 & - & - \\
\hline CRP (0-18 mg/L) & 1 & - & 62.5 & - & 10.3 \\
\hline ESR (0-10 mm/h) & - & - & 40 & - & 55 \\
\hline COVID-19 treatment & None & HCQ, azithromycin & $\begin{array}{l}\text { HCQ, azithromycin, } \\
\text { hydrocortisone, } \\
\text { tocilizumab }\end{array}$ & $\begin{array}{l}\text { HCQ, azithromycin, } \\
\text { prednisone }\end{array}$ & None \\
\hline Chest X-ray at the initial COVID-19 evaluation & $\begin{array}{l}\text { No acute } \\
\text { cardiopulmonary } \\
\text { process }\end{array}$ & $\begin{array}{l}\text { Diffuse advanced } \\
\text { interstitial lung } \\
\text { disease }\end{array}$ & $\begin{array}{l}\text { Bibasilar reticular } \\
\text { infiltrates, later } \\
\text { progressed to } \\
\text { bilateral pulmonary } \\
\text { opacities consistent } \\
\text { with ARDS }\end{array}$ & $\begin{array}{l}\text { Bibasilar atelectasis, } \\
\text { bilateral pulmonary } \\
\text { opacities }\end{array}$ & $\begin{array}{l}\text { No acute } \\
\text { cardiopulmonary } \\
\text { process }\end{array}$ \\
\hline Outcome & $\begin{array}{l}\text { Discharged to home } \\
\text { from ED, doing well } \\
\text { at } 2 \text {-week follow-up }\end{array}$ & $\begin{array}{l}\text { Did not require } \\
\text { hospitalization, } \\
\text { complete recovery } \\
\text { at } 2 \text {-week follow-up }\end{array}$ & $\begin{array}{l}\text { Death due to } \\
\text { pulmonary embolism } \\
\text { after prolonged } \\
\text { hospitalization } \\
\text { requiring ICU } \\
\text { admission }\end{array}$ & $\begin{array}{l}\text { Discharged from the } \\
\text { ICU, doing well at } \\
\text { 2-week follow-up }\end{array}$ & $\begin{array}{l}\text { Did not require } \\
\text { hospitalization, } \\
\text { complete recovery } \\
\text { at } 2 \text {-week follow-up }\end{array}$ \\
\hline
\end{tabular}

Available relevant laboratory data, treatment, and outcome at follow-up are presented.

WBC, white blood cell; Abs, absolute; CRP, C-reactive protein; ESR, erythrocyte sedimentation rate; $L D H$, lactate dehydrogenase; ED, emergency department; HCQ,

hydroxychloroquine; ARDS, acute respiratory distress syndrome; ICU, intensive care unit. 


\section{CASE PRESENTATION}

We identified 5 out of 238 sarcoidosis patients who were infected with SARS-Cov-2 during the study period. All patients were of African American descent. The most common presenting symptom was cough. One patient had an atypical presentation of gastrointestinal discomfort and diarrhea. Four patients recovered completely despite having comorbidities and being on chronic immunosuppression. Two of the five patients did not receive any additional treatment for COVID-19. Three of the five patients received hydroxychloroquine (HCQ) and azithromycin for treatment for COVID-19. No changes were made to the patients' current immunosuppressive regimen. They also did not experience significant relapses of sarcoidosis from the time of COVID-19 diagnosis to date. One patient died after developing a likely thromboembolic event during hospitalization in the intensive care unit (ICU). Additional clinical characteristics of these patients are summarized in Table 1. The clinical data, including symptoms, laboratory data, and outcomes, are included in Table 2.

\section{DISCUSSION}

The case fatality rate of COVID-19 is estimated to be $1-6 \%$ in the general population (4). Currently, the Center for Disease Control and Prevention (CDC) lists several risk factors for severe COVID-19, including immunocompromised status (5). However, preliminary data from an observational study of 320 Italian patients on immunosuppressive therapy for rheumatoid arthritis did not show increased risk of respiratory or lifethreatening complications from SARS-CoV-2 compared with the general population (6). Indeed, it has been postulated that the pathogenesis of severe COVID-19 disease is in large part due to virally driven hyperinflammation that is perpetuated by the host immune response (7-9). Analysis from a cohort of COVID-19 cases from Wuhan, China revealed that patients requiring ICU had increased levels of pro-inflammatory cytokines (10).

Our findings do not provide any conclusions on the incidence rate of SARS-CoV-2 infection in patients with

\section{REFERENCES}

1. Sweiss NJ, Korsten P, Syed HJ, Syed A, Baughman RP, Yee AMF, et al. When the game changes: Guidance to adjust sarcoidosis management during the COVID-19 pandemic. Chest. (2020) 158:892-5. doi: 10.1016/j.chest.2020. 04.033

2. Mirsaeidi M, Machado RF, Schraufnagel D, Sweiss NJ, Baughman RP. Racial difference in sarcoidosis mortality in the United States. Chest. (2015) 147:43849. doi: $10.1378 /$ chest.14-1120

3. Chowkwanyun M, Reed AL. Racial health disparities and COVID19 - caution and context. New Engl J Med. (2020) 383:201-20. doi: 10.1056/nejmp2012910

4. Sun P, Lu X, Xu C, Sun W, Pan B. Understanding of COVID-19 based on current evidence. J Med Virol. (2020) 92:548-51. doi: 10.1002/jmv. 25722 sarcoidosis, nor on the severity or overall outcome of immunocompromised sarcoidosis patients affected by COVID19 disease. However, our preliminary experience suggests that African American patients with chronic sarcoidosis treated with disease-modifying anti-rheumatic drugs (DMARDs) or antitumor necrosis factor (TNF) therapy do not seem to be at increased risk of respiratory or life-threatening complications from SARS-CoV-2 compared with the general population. Better understanding of the implications of COVID-19 in patients with sarcoidosis and the effects of immunosuppressive therapies on COVID-19 infection outcome is urgently needed to guide clinicians in patient care. At the present time, we advocate for maintaining a high level of vigilance and strict followup in this patient population, including the exclusion of superimposed infections.

\section{DATA AVAILABILITY STATEMENT}

The raw data supporting the conclusions of this article will be made available by the authors, without undue reservation.

\section{ETHICS STATEMENT}

Written informed consent was obtained from the individual(s) for the publication of any potentially identifiable images or data included in this article.

\section{AUTHOR CONTRIBUTIONS}

NS identified patients of interest within the cohort. MMa wrote the manuscript with assistance from CA, AA, DP, PF, and MMi. All authors contributed to the article and approved the submitted version.

\section{FUNDING}

Funding for publication of this article was provided by the Bernie Mac Foundation STAR Clinic. 
10. Huang C, Wang Y, Li X, Ren L, Zhao J, Hu Y, et al. Clinical features of patients infected with 2019 novel coronavirus in Wuhan, China. Lancet. (2020) 395:497-506. doi: 10.1016/s0140-6736(20)30183-5

Conflict of Interest: The authors declare that the research was conducted in the absence of any commercial or financial relationships that could be construed as a potential conflict of interest.
Copyright $\odot 2020$ Manansala, Ascoli, Alburquerque, Perkins, Mirsaedi, Finn and Sweiss. This is an open-access article distributed under the terms of the Creative Commons Attribution License (CC BY). The use, distribution or reproduction in other forums is permitted, provided the original author(s) and the copyright owner(s) are credited and that the original publication in this journal is cited, in accordance with accepted academic practice. No use, distribution or reproduction is permitted which does not comply with these terms. 